\title{
POLÍTICAS PÚBLICAS EM TRABALHO, EDUCAÇÃO E TECNOLOGIA: UMA HISTÓRIA EM MOVIMENTO
}

\author{
PUBLIC POLICIES AT WORK, EDUCATION AND TECHNOLOGY: A HISTORY IN COURSE
}

Marlene Ribeiro ${ }^{1}$

Resumo Políticas públicas em trabalho, educação e tecnologia têm sido objeto de intensos confrontos entre forças sociais antagônicas. Este é o tema deste artigo, que visa a levantar questões para um debate sobre algumas das políticas públicas na área da educação profissional e tecnológica. Com este propósito, resgata-se a discussão sobre a relação trabalho-educação - que, no início da década de 1980, justificou a criação do grupo de trabalho intitulado "Trabalho e educação", na Associação Nacional de Pós-Graduação e Pesquisa em Educação (Anped) - para, a partir daí, acumular elementos que permitam avaliar os avanços e retrocessos das atuais políticas públicas para a educação profissional e tecnológica. $\mathrm{O}$ artigo fundamenta-se no acompanhamento e participação no debate sobre trabalho-educação na Lei de Diretrizes e Bases da Educação Nacional (LDB) e em pesquisas sobre o tema.

Palavras-chave trabalho-educação; movimentos sociais e educação; políticas públicas.
Abstract Public policies at work, education and technology have been object of active confrontation between antagonistic social forces. This is the theme of this article that aims to initiate a debate about some public policies on professional and technical education field. In this sense, we recover the discussion on work-education relationship - which at the beginning of the 1980's justified the creation of the work team called "Work and Education", at the National Association of Post Graduation and Research (Associação Nacional de Pós-Graduação e Pesquisa em Educação - Anped) - to gather elements which enable the assessment of advances and retrocession of current public policies related to professional and technical education. The article is base don the follow-up and participation in the debate on work-education of the Guidance Law and Basis of National Education (Lei de Diretrizes e Bases da Educação Nacional - LDB) and on researches about this theme.

Key words work-education; social activity and education; public policies. 


\section{Introdução}

Políticas públicas em trabalho, educação e tecnologia é um tema relevante numa sociedade em que escasseiam os empregos protegidos por legislação social e se multiplicam os desempregados, os trabalhadores informais e/ou autônomos e as pseudocooperativas. Recorrendo à história, tomamos consciência de que políticas públicas são alvo de confronto entre forças sociais antagônicas. De um lado, estão as forças que personificam o capital e que, por isso, exigem a diminuição dos custos com a reprodução da força de trabalho, que é abundante e, em grande parte, desnecessária aos processos produtivos automatizados e informatizados. De outro, e com sua capacidade de 'negociação' diminuída, estão os trabalhadores que precisam encontrar trabalho para viver e, para isso, também precisam de uma formação científica e tecnológica cada vez mais qualificada e de caráter público.

Trataremos deste tema, visando a propor questões para um debate sobre algumas das políticas públicas na área da educação profissional e tecnológica. Com essa finalidade, resgatamos a discussão sobre a relação trabalho-educação que, no início da década de 1980, fundamentou a criação do grupo de trabalho denominado "Trabalho e Educação" da Anped. Com isso, pensamos reunir elementos que permitam avaliar os avanços e retrocessos das políticas públicas para a educação, em especial, as destinadas à educação profissional e tecnológica.

O tema é amplo, e não pretendemos esgotá-lo, pois tem sido objeto de inúmeras e ricas reflexões produzidas por pesquisadores vinculados àquele GT da Anped. O resgate que fazemos da produção em trabalho-educação, para nele inscrevermos o debate sobre políticas públicas em trabalho, educação e tecnologia, encontra sua razão de ser na necessidade de escrever a história da educação sob a ótica dos trabalhadores e de suas lutas, para que esta história seja incorporada aos currículos de formação não só dos técnicos e tecnólogos, mas, sobretudo, de seus formadores, nas licenciaturas e nos cursos de pedagogia. Justifica-se, ainda, pela escassez de estudos que reflitam os vínculos entre os debates e propostas para a educação pública e os movimentos sociais organizados dos trabalhadores das diferentes categorias, que lutam por trabalho digno e por terra de trabalho. Assim, abordamos neste texto as políticas públicas em trabalho, educação e tecnologia, focalizando a história no movimento produzido pela luta de classes.

$\mathrm{O}$ artigo fundamenta-se em experiências de educação popular, particularmente de formação sindical ${ }^{2}$, com trabalhadores urbanos e rurais no Amazonas, nos anos 80; na militância sindical ${ }^{2}$; em pesquisas sobre trabalhoeducação que desenvolvemos desde 1984, no momento com apoio do CNPq; na produção que decorre destas pesquisas; e na participação em seminários, simpósios e congressos, em especial no GT "Trabalho e educação" da Anped, que nos permitiram acompanhar de perto e, algumas vezes, até intervir no 
debate sobre o trabalho como princípio educativo com vistas à elaboração do projeto popular de Lei de Diretrizes e Bases da Educação Nacional (LDB).

\section{A relação trabalho, educação e tecnologia encarnada nos movimentos sociais}

O processo de construção do projeto popular e democrático de sociedade protagonizado pelos movimentos sociais populares impõe a disciplina constante de se retomar a história que a ideologia neoliberal esforça-se por apagar ou confundir. Se não o fizermos, corremos o risco de partir sempre do zero, sem avançar com as vitórias nem aprender com as derrotas. A história do pensamento educacional brasileiro começa a adquirir contornos próprios a partir das décadas de 1950 e 1960, com as experiências de educação popular enraizadas nos movimentos sociais populares (Ribeiro, 1999). Interrompidos pela ditadura militar de 1964, os movimentos sociais retornam à cena pública no final da década de 1970, realimentando o debate sobre trabalho e educação e as propostas para o projeto popular de LDB. Numa perspectiva de mais longo alcance estas propostas e o debate sobre a escola unitária de formação omnilateral, tendo o trabalho como princípio educativo, estão relacionados aos movimentos revolucionários do século XIX e da primeira metade do XX e às concepções geradas por estes, que relacionam trabalho e educação confirmando a necessária relação entre movimentos sociais e educação (Ribeiro, 2004).

Do mesmo modo que os movimentos revolucionários europeus fecundaram propostas que vêm sendo aperfeiçoadas, também os debates sobre trabalho-educação que atravessaram a construção do projeto popular de LDB estavam encarnados nas lutas sociais dos trabalhadores brasileiros, retomadas em 1978, ainda durante a ditadura militar (Maroni, 1982). Ocorre, nesse mesmo ano, a primeira greve dos metalúrgicos, sob a liderança de um grupo de trabalhadores organizados como oposição à direção do Sindicato dos Metalúrgicos da cidade de São Paulo. Coincidentemente, acontece o I Seminário de Educação Brasileira, realizado pela Faculdade de Educação da Universidade Estadual de Campinas (Unicamp), também em São Paulo (Educação \& Sociedade, 1979; Brandão, 1980). Ambos - greve e seminário - marcam o início de um processo de enfrentamento ao regime militar e de crítica à reforma educacional imposta pelas leis $\mathrm{n}^{0}$ 5.540/68 (ensino superior) e $\mathrm{n}^{0} 5.692 / 71$ (ensino de primeiro e segundo grau). Este foi apenas o início das greves, manifestações e protestos que se multiplicaram em todo o país durante os anos 80 , conquistando uma 'abertura' política, ainda que conduzida pela ditadura ${ }^{3}$.

Nesse contexto, educadores brasileiros pautam o debate sobre a relação trabalho-educação, levantando questões sobre: a escola, a metodologia 
de ensino e os conteúdos que interessam às camadas populares ${ }^{4}$, tendo por referência autores do pensamento socialista. Nossa hipótese é que o tema trabalho-educação, objeto de intensas discussões e profícua produção nos anos 80 , tenha suas raízes naqueles movimentos sociais e nas questões que eles suscitaram à escola pública enquanto um espaço privilegiado de educação das camadas populares. Nesse caso, concordamos com Maria da Glória Gohn (1992, p. 7), para quem as reformas e propostas educacionais são datadas e "correspondem a períodos de crise na economia, de redefinição do modelo de acumulação vigente e de constituição de novos atores sociais como sujeitos da cena política nacional".

O debate então instaurado gira em torno do que poderia ser uma escola comprometida com os interesses das camadas populares, tendo como pano de fundo o processo de reorganização dos movimentos sociais populares, que imprimiriam sua feição à sociedade e, conseqüentemente, à educação brasileira. Vale lembrar que a força da greve dos metalúrgicos paulistas, em 1978, ao mesmo tempo em que conquistou apoio de grande parte da população, obrigando a ditadura a recuar, também estimulou alguns pesquisadores, no âmbito das ciências sociais, a formularem uma nova visão dos trabalhadores brasileiros. Do papel negativo que lhes era conferido pelos historiadores, passam os trabalhadores a se constituir em sujeitos da história (Paoli, Sader e Telles, 1983). A polêmica instaurada entre pesquisadores educacionais a partir de 1978 vai assumindo contornos cada vez mais definidos, tendo como horizonte a defesa da educação pública, embora com posições divergentes quanto ao sentido de uma escola unitária do trabalho, constituindo-se tal concepção no eixo que sustenta o conjunto de propostas para o projeto popular de LDB.

Dois autores desencadearam o debate travado nos anos 80 sobre a escola negada às camadas populares: Dermeval Saviani e Guiomar Namo de Mello. O primeiro destaca a importância da educação como instrumento de luta das classes subalternas. Inspirado em Gramsci ${ }^{5}$, julga ser possível ao educador extrair do senso comum do educando o núcleo elaborado em bom senso ${ }^{5}$, entendendo a educação como um instrumento de luta. Esta tarefa consiste na passagem do senso comum à consciência filosófica, ou seja, "de uma concepção fragmentária, incoerente, desarticulada, implícita, degradada, mecânica, passiva e simplista a uma concepção unitária, coerente, articulada, explícita, original, intencional, ativa e cultivada" (Saviani, 1980, p. 10).

Focalizando a escola pública, Mello (1988) ${ }^{6}$ afirma que esta deve fazer bem o que se propõe, isto é, ensinar com competência orientada pelo bom senso. Tal competência pressupõe o domínio dos conteúdos e dos métodos para transmiti-los às crianças que não apresentem condições adequadas de aprendizagem. Sob a ótica desta autora, a competência técnica transformase em vontade política quando se percebem as possibilidades e os limites 
objetivos a uma atuação devidamente competente, no sentido de oferecer ao maior número possível de crianças o conhecimento escolar, como instrumento de organização das camadas populares. Não por acaso, a competência, uma qualidade individual, coloca-se hoje, mais de 20 anos depois deste debate, em confronto com a qualificação profissional enquanto relação social, encontrando-se no centro do atual debate sobre a reforma da educação profissional e tecnológica ${ }^{7}$.

Na mesma linha de pensamento de Guiomar Mello, cuja tese de doutorado foi orientada por Dermeval Saviani ${ }^{8}$, colocam-se Paiva (1984), Libâneo (1986) e Oliveira e Duarte (1987), que defendem a necessidade de que a escola pública cumpra sua função de repassar, sob a forma de conteúdos, os conhecimentos socialmente produzidos. Sem estes, as camadas populares ficam desprovidas de instrumentos para uma visão crítica da realidade e para formular suas estratégias de luta. Como Mello, esses autores pensam que a competência técnica em bem transmitir os conteúdos curriculares é que definirá o compromisso político do educador com a construção do projeto popular de sociedade.

Analisando experiências de educação popular, decorrentes das críticas ao autoritarismo pós-1964, principalmente as vinculadas às pastorais populares, Paiva (1984) afirma que tais experiências caíram no extremo do "populismo pedagógico". Este, segundo a autora, anula o papel e a competência do professor na organização de um plano de trabalho para orientar a aprendizagem do aluno, deixando em segundo lugar a qualidade do ensino. Libâneo (1986) reconhece a importância da escola pública para as camadas populares no que tange à ampliação das oportunidades de qualificação e à apropriação dos conhecimentos produzidos socialmente, que se constituem em patrimônio da humanidade. Para o autor, “a contribuição essencial da educação escolar para a democratização da sociedade consiste no cumprimento de sua função primordial, o ensino" (Libâneo, 1986, p. 12).

Nesse sentido, a escola teria a função de transmitir conteúdos e habilidades, de modo a contribuir, no nível individual, para a satisfação de necessidades imediatas quanto à colocação no mercado de trabalho e, no nível social, para fornecer elementos teóricos aos alunos, a fim de que estes possam compreender e atuar no processo coletivo de mudança social. "Para isso, o autor propõe a pedagogia crítico-social dos conteúdos que vê a escola como difusora de saber sem perder de vista seu vínculo com a base social numa perspectiva transformadora" (Ribeiro, 1991, p. 6). Investigando a relação entre o técnico e o político, Oliveira e Duarte (1987) concluem pela necessidade de democratizar conhecimentos básicos (leitura, escrita e aritmética), o que corresponde à função específica da escola pública, como pensam também Paiva e Libâneo. O técnico, entendido como aquele que detém um saber fazer pedagógico, assume uma dimensão política de ensinar 
o melhor possível, ou seja, de transmitir conteúdos e habilidades para que se transformem em armas com as quais os trabalhadores possam enfrentar os desafios da sociedade e obter melhores condições tanto para se organizar, quanto para responder a suas necessidades de conseguir trabalho.

A essa concepção de escola pública assentada na competência técnica do professor e cuja função seria a socialização do conhecimento na perspectiva de formar o cidadão crítico, contrapõe-se outra visão, no sentido de uma escola gerada na luta pela construção de um projeto popular de sociedade em que o compromisso político com as camadas populares é que definirá a competência técnica e os conhecimentos a serem transmitidos e produzidos. A importância da escola pública para as camadas populares, tendo como horizonte a transformação da sociedade, é o ponto comum entre as concepções, que, entretanto, divergem quanto ao papel que a escola desempenha neste processo de transformação.

No período de 1978 a 1990, instaura-se um debate bastante rico, alicerçado nas lutas sociais e na organização dos trabalhadores em associações, sindicatos e centrais sindicais, no interior das quais também é deslanchado um processo de discussões e propostas de reformulação curricular dos cursos de pedagogia e das licenciaturas, iniciado em 1980. Gadotti (1986), Santos (1985), Arroyo (1986) e Nosella (1983) formulam análises que contrariam aquelas concepções anteriormente apresentadas.

Tendo como interlocutores Saviani e Mello, Gadotti (1986) pensa que a consciência de classe forma-se em estreita coesão com os interesses e práticas de classe, não podendo ser doada ou introduzida de fora por pessoas pretensamente 'iluminadas'. Já afirmaram Marx e Engels (1984), na $11^{\text {a }}$ tese sobre Feuerbach, que a filosofia enquanto reflexão não serve às camadas populares. Baseado nesses autores, Gadotti defende que a libertação é um fato histórico, e não intelectual. Na concepção idealista e burguesa, a ótica de classe é substituída pela competência técnica capaz de tornar-se compromisso político. Todavia, para Gadotti, a consciência de classe não é um conceito abstrato; ela tem dois sentidos, um particular, ligado à prática social, e um metodológico, tendo como objetivo a conquista do socialismo. Na ótica do capital, interessa reduzir os trabalhadores ao estado de infantilidade; já na ótica das camadas populares, o essencial não é adquirir saber técnico para aumentar a mais-valia, mas adquirir maturidade para tornar-se classe dirigente.

Na mesma direção de Gadotti, Santos (1985) afirma que a escola capitalista transmite conteúdos sob a forma de pacotes, como se fossem produtos prontos, acabados, sem história. Desse modo, permanece oculto o processo de produção do conhecimento em relações contraditórias de exploração e apropriação do produto do trabalho, geradoras de classes sociais antagônicas. Assim, os saberes didatizados, resumidos em conteúdos e selecionados 
segundo os interesses da classe que detém o poder econômico-político, perdem o seu caráter social e se tornam metafísicos. Uma escola voltada aos interesses dos trabalhadores tem por finalidade não só distribuir, mas, fundamentalmente, produzir os conhecimentos que interessam a esses sujeitos sociais. É desta finalidade que decorre o compromisso político de reconhecer que os trabalhadores já estão na escola, que eles trazem uma experiência, um saber, e que o ensino precisa tomar esta experiência e este saber como ponto de partida, trabalhando sob um novo eixo em que educadores e educandos sejam co-produtores do novo conhecimento.

Nosella (1983) confronta suas concepções com as de Mello em debate reproduzido pela revista Educação \& Sociedade sobre a questão da competência técnica versus compromisso político, embora ambos tenham sido orientados no doutorado por Dermeval Saviani. Nosella afirma que a competência ou a incompetência são qualificações atribuídas por uma concepção de cultura historicamente determinada. O processo histórico de identificação do trabalhador com a sua própria classe acontece através de um processo educativo distinto do que propõe a cultura burguesa. "Se o horizonte político de per se só não é ainda a capacidade de se caminhar, é, no entanto, a orientação concreta que informa toda a técnica e toda a instrumentação educativa" (Nosella, 1983, p. 94).

A eficácia de uma nova técnica só pode ser testada nas práticas de luta dos trabalhadores. Para o autor, sem compromisso com a luta política não há condições objetivas para a construção de uma competência capaz de superar processos de ensino-aprendizagem fragmentados e assistencialistas, nem de alcançar objetivos historicamente delineados de uma educação que supere a dualidade da formação de dirigentes em contraposição à formação de subordinados. Saviani (1983) ${ }^{9}$, em Competência política e compromisso técnico ou (o pomo da discórdia e o fruto proibido), procurou, de certa forma, conciliar as posições defendidas por Mello e Nosella nos textos mencionados ${ }^{9}$.

Arroyo (1986, p. 15) alerta "contra o perigo de nos deixarmos ofuscar pelo valor da escolarização em si", e desloca as preocupações centradas na função da escola, nos conteúdos e na metodologia, para a compreensão da relação entre a escola pública e as camadas populares. Conforme este autor, não se pode afirmar que uma escola destas e para estas camadas tenha fracassado, pois, de fato, esta escola nunca existiu. Na sociedade capitalista, a escola é também uma instituição de classe, apesar das contradições que a atravessam. Construir a escola possível das classes populares exige a compreensão de como se produz o que tem sido rotulado de "fracasso escolar"; há necessidade de se ter clareza em relação à responsabilidade do Estado pela educação pública enquanto direito universal do cidadão que não vem sendo cumprido, lembra Arroyo. Para este autor, não será possível ensinar para a participação e a emancipação das camadas populares “com os mesmos livros 
didáticos, a mesma estrutura e a mesma relação pedagógica com que se ensinaram a ignorância e a submissão de classe" (Arroyo, 1986, p. 20).

\section{O trabalho como princípio educativo no projeto popular de LDB}

A polêmica em torno da relação trabalho-educação aqui retraçada, ou, mais propriamente, da escola que interessa às camadas populares, esteve no bojo do processo de elaboração da nova Constituição da República Federativa do Brasil, promulgada em 1988. Setores comprometidos com a educação pública organizaram-se, primeiramente, para formular e garantir a aprovação de emendas populares na Constituinte e, depois, para elaborar propostas que viriam a se constituir em projeto de LDB, exigido para regulamentar o capítulo três, "Da Educação, da Cultura e do Desporto", da Constituição. Nesse contexto, os pensadores da educação passam a concentrar suas preocupações na elaboração do projeto de LDB, convergindo o debate para um ponto comum:

\footnotetext{
“o trabalho como princípio educativo - eixo da escola unitária destinada a formar o homem omnilateral e que se constitui na temática de encontros regionais e nacionais organizados por entidades representativas de segmentos ligados à educação" (Ribeiro, 1991, p. 9).
}

Como já afirmamos, a proposta não é original. Radica-se nas experiências de luta dos trabalhadores europeus e russos em suas tentativas de implantar o socialismo. Marx e Engels são as referências originais, embora a construção da proposta tenha avançado com Gramsci e, posteriormente, no período pós-revolucionário russo, tenha sido experimentada por Lênin. Ainda que tenham o trabalho como eixo comum e bebam nas mesmas fontes - Marx, Engels, Gramsci e Lênin -, as interpretações e propostas feitas pelos pensadores brasileiros divergem no mesmo sentido das polêmicas analisadas anteriormente.

A partir de alguns indícios, tendo clareza de que esta é uma 'visão interessada', podem ser identificados dois grupos. O primeiro chama a atenção para a necessidade de se definir com clareza a função do então chamado segundo grau (lei $\mathrm{n}^{\circ} 5.592 / 71$ ), que poderia identificar-se com a politecnia proposta no pensamento socialista. Ao mesmo tempo, o grupo apresenta propostas para viabilizar um ensino politécnico a ser conquistado, porque, reconhecem os autores, a sociedade capitalista impõe limites ao avanço das camadas populares. O segundo grupo tenta recuperar a concepção original do trabalho como princípio educativo, forjada na luta para destruir as relações capitalistas de expropriação da terra, de exploração e apropriação do 
produto do trabalho, presente em programas político-partidários cujo objetivo era a conquista do socialismo. Reconhecendo que a lei é uma questão política que envolve relações de força, que os trabalhadores são constituintes essenciais destas relações e que as propostas para a educação devem corresponder às condições históricas concretas, o segundo grupo aponta algumas alternativas que os movimentos de defesa da educação pública deveriam empunhar na luta para garantir uma nova legislação educacional segundo seus interesses.

Um debate intitulado "Trabalho-educação-escola e a Nova Lei de Diretrizes e Bases: vamos escrever esta lei?" foi promovido pela Associação dos Professores do Ensino Oficial do Estado de São Paulo (Apeoesp), reunindo os pesquisadores Miguel Arroyo, Dermeval Saviani, Paolo Nosella e Lucília Machado. Para a elaboração deste artigo consultamos os textos resultantes desse debate, publicados em setembro de 1989, pela Revista de Educação da Apeoesp.

Saviani (1989) afirma que o primeiro grau organiza-se em torno do conceito e do fato do trabalho, enquanto o ensino superior caracteriza-se pela profissionalização. É no ensino de segundo grau que as relações entre educação e trabalho precisariam estar explicitadas, envolvendo o domínio teórico-prático sobre como se articulam o conhecimento e o processo produtivo. O autor reconhece os limites estruturais da sociedade brasileira para propor mudanças à educação. Entretanto, aponta a necessidade de serem elaboradas estratégias de curto e longo prazo para implantar uma formação politécnica, que, para Saviani, concentra-se nas modalidades em que se assentam os variados processos e técnicas de produção industrial.

Kuenzer (1991) concorda com Saviani ao afirmar que a função do segundo grau precisa ser definida com maior clareza. Acrescenta que a educação pública padece de falta de democratização e de recursos, sendo que o equacionamento de tais questões depende de vontade política. Por isso, suas preocupações em torno da escola possível, na época, passavam pela 'amarração', na LDB, de artigos que garantissem recursos e efetiva democratização não só do ensino de segundo grau, mas do saber científico e técnico. Para isso seria essencial ouvir os interessados, isto é, os trabalhadores, que sempre estiveram ausentes do processo de formulação das leis.

Aprofundando a discussão, Kuenzer constata que o ensino de segundo grau caracteriza-se pela dualidade estrutural devido ao seu conteúdo de classe, uma denúncia que faz até hoje. Este ensino oferece uma formação predominantemente intelectual para os que serão dirigentes, e outra formação, predominantemente técnico-prática, para os que serão trabalhadores. Para estes, a educação não é necessariamente profissionalizante, mas os instrumentaliza precariamente para continuarem sendo trabalhadores, aceitando a subordinação. Tomando o trabalho como princípio educativo, uma escola 
de segundo grau para os trabalhadores "terá necessariamente de partir do princípio da democratização do saber científico e tecnológico para o conjunto da sociedade brasileira" (Kuenzer, 1991, p. 119), trazendo em seu bojo, portanto, uma nova relação teoria-prática. Mas a autora também reconhece que esse é um problema político, cuja solução aponta para a transformação da sociedade, estando, portanto, além da escola. Considerando o desenvolvimento científico e tecnológico da sociedade e tendo a politecnia como horizonte utópico, Kuenzer propõe uma concepção de escola que adote o trabalho como princípio educativo, possua uma estrutura única em termos de não separação entre teoria e prática, tenha conteúdo politécnico e inclua o domínio das linguagens e códigos próprios de cada área do conhecimento.

Nessa mesma linha, porém ampliando a concepção de Saviani, Machado $(1989 a)^{10}$ defende o ensino politécnico no segundo grau. Justifica sua posição apontando para o momento histórico da sociedade brasileira, em que é possível observar as significativas transformações introduzidas pelo avanço tecnológico nos processos produtivos e o aumento considerável da população de estudantes trabalhadores. A educação, segundo a autora, deve estar em sintonia com as necessidades manifestas por milhares de jovens trabalhadores, bem como incorporar à metodologia de ensino o conhecimento das técnicas básicas que alimentam o processo de produção industrial. Buscando a origem grega da palavra tecnia, Machado explicita sua compreensão de ensino politécnico, que não pode ser entendido como mero treinamento em técnicas diversificadas de produção, mas compreende uma mediação entre a formação geral e a formação técnica. Esta é uma reivindicação que se mantém atual e se amplia, compreendendo a reforma dos cursos de licenciatura e de pedagogia.

Como objetos de estudo da educação politécnica, a autora inclui as bases das ciências contemporâneas, os princípios gerais da tecnologia, as particularidades dos métodos tecnológicos e os princípios da organização da produção e da economia. Os conteúdos estariam articulados em três dimensões: os objetos do trabalho humano, os instrumentos de trabalho e as relações e a organização social do trabalho. Machado (1989a,p30), como os demais autores, também aponta as "limitações sócio-estruturais que restringem as suas possibilidades numa sociedade como a brasileira", ao mesmo tempo em que sinaliza para a possibilidade de organização das camadas populares na luta pela construção de uma nova hegemonia, que definirá os contornos do 'máximo possível' a ser conquistado por estas camadas. Nessa luta está inserida a escola unitária para todos, pública e laica.

Os autores, neste primeiro grupo, manifestam uma preocupação com a definição da politecnia e com a viabilidade de sua implantação como escola unitária em nível de primeiro e segundo graus, hoje ensino fundamental e médio, considerando as transformações que ocorrem na base técnica da 
produção, bem como o aumento da população de jovens trabalhadores, e, em conseqüência, a necessidade de ampliar a oferta de escolas públicas.

Outros autores deslocam suas análises para a relação entre a escola e a sociedade, para, a partir daí, levantar questões. Nessa linha, Frigotto (1989) apresenta divergências em relação aos autores anteriores, questionando como é possível, em uma sociedade em que a divisão do trabalho produz o homem unilateral e que exige um trabalhador polivalente, "instaurar, concretamente, uma prática educativa que se coloque na dimensão da 'omnilateralidade' do homem trabalhador, a qual requer uma formação politécnica?" (Frigotto, 1989, p. 17).

Transferindo a definição da politecnia aplicada ao ensino de segundo grau para as forças sociais cujo movimento redefine a escola, Frigotto constrói seu argumento sobre três pressupostos: a) as práticas pedagógicas são condicionadas pelas práticas sociais estabelecidas através de relações materiais de produção; b) não há uma hierarquia mecânica, mas uma relação dialética entre as citadas práticas; c) a democratização do ensino se insere na luta mais ampla pela democratização das relações sociais de produção, no que concorda com Lucília Machado.

Frigotto critica severamente o que, naquele momento, considerava crise de superficialidade teórica, faz um inventário das teorias que relacionam trabalho e educação, para, finalmente, concluir sobre a necessidade de se interrogar a natureza das contradições presentes nas novas bases científicas e tecnológicas sobre as quais se assentam os processos produtivos. Efetuando um resgate histórico do conceito de politecnia, o autor reforça a necessidade de se apresentar propostas que respondam às condições históricas atuais. A conquista da politecnia - uma tarefa política e prática - só é possível no interior de novas relações arrancadas das velhas relações sociais e pedagógicas caracterizadas pela negatividade. O autor salienta a inviabilidade de propostas programáticas no nível do "dever ser" e recomenda "um posicionamento frente às possibilidades da formação politécnica, calcado naquilo que (...) denominamos perspectiva histórico-analítica em contraposição às visões instrumentalistas de escola" (Frigotto, 1989, p. 26).

Nosella tem aprofundado estudos sobre a obra de Gramsci e, para o mencionado debate, traz importantes contribuições à compreensão da proposta de escola unitária. Nosella (1989) resgata o contexto em que se gera a proposta para a escola única do trabalho, construída sobre as discussões pedagógicas que ocorriam em torno da Reforma Gentile, na Itália, em 1923, das experiências educativas realizadas na Rússia após a Revolução de 1917 e das atividades formativas do Círculo de Cultura, do jornal De Ordine Nuovo, em Turim, entre 1919 e 1920. A escola unitária do trabalho em Gramsci, segundo Nosella, teria um caráter desinteressado, ou seja, formativo. Compreenderia o primeiro e o segundo graus, diferenciando-se apenas pelo 
caráter didático-metodológico. A profissionalização ou formação interessada, sem perder a dimensão formativa, seria feita no terceiro grau ou curso superior. O elemento novo trazido pelo autor, e que nos interessa particularmente, é o fato de a escola unitária do trabalho ser uma proposta alternativa de política educacional e cultural, elaborada em período revolucionário, na Itália da década de 1920, para ser colocada em prática pelo Partido Comunista Italiano, apenas quando e se este assumisse o poder.

Segundo Nosella, a chave teórica em que Gramsci (1989) conclui seu pensamento a respeito da educação está no terceiro texto, de apenas uma página, no Caderno 12. Nesse texto ${ }^{12}$, o autor desenvolve o seguinte raciocínio: a escola tradicional morre com o advento da sociedade industrial e a escola ativa, de Dewey, apesar de representar um avanço, não tem condições de oferecer alternativas à crise educacional. Caberia ao partido, no caso o Comunista, que representava a classe trabalhadora italiana - a nova classe -, oferecer a solução da crise pedagógica, substituindo o ensino tradicional pela moderna civilização do trabalho industrial. Esta proposta se concretizaria através do estudo da prática-trabalho na sociedade moderna (politecnia), fundamentado na ciência-trabalho (tecnologia) e na históriatrabalho (humanismo). A escola, sob uma ótica gramsciana, teria o sentido mais amplo de formar intelectuais de um novo tipo, dirigentes de classe que seriam, ao mesmo tempo, especialistas, ou técnicos, e políticos.

Trazendo a questão para a reforma educacional que se discutia no Brasil, Nosella não discorda das análises anteriormente apresentadas por Frigotto. Recupera uma crítica feita por Marx à tendência de o avanço tecnológico, no sistema capitalista, exigir um trabalhador polivalente e sempre preparado para desempenhar tarefas diferenciadas em razão das mudanças introduzidas nos processos produtivos. As escolas politécnicas, nesse sentido, estariam servindo a essa necessidade do capital. A verdadeira instrução socialista seria tecnológica. Suas objeções são feitas aos autores de modo geral, quanto ao uso indistinto dos termos politecnia e tecnologia com o mesmo significado. Em respeito ao sentido da concepção que é explicitada nas obras de Marx, Gramsci, e Manacorda (1990), enquanto estudioso destes clássicos, Nosella opta pela expressão 'escola tecnológica'.

Arroyo (1989) também participa deste debate, constatando o estreitamento, na década de 1980, do vínculo entre trabalho e educação, que anteriormente era feito por escolas profissionalizantes. Para ele, as mudanças ocorridas nos processos produtivos nas últimas décadas deslocam milhares de camponeses para os centros urbanos, transformando-os em trabalhadores assalariados. Este processo exige definições teórico-práticas a respeito de uma escola das camadas populares, porque estas têm demonstrado em suas lutas que são possuidoras de culturas e saberes não adquiridos na escola. $\mathrm{O}$ autor insiste em questionar se o ensino, como função da escola, foi ou ainda 
é resultante de uma demanda das camadas populares. As circunstâncias históricas em que se efetiva a educação dos trabalhadores, mais especificamente a materialidade das escolas, precisa ser educada, por isso é muito insignificante que sejam colocadas meras recomendações para a elaboração de uma nova lei, no caso a LDB, que não terão forças de se concretizar. É possível constatar essa observação feita por Arroyo, ainda hoje, na política pública destinada à educação básica, na valorização do magistério, na distribuição dos recursos para a educação pública e mesmo na consecução das determinações legais. A força da representação do capital no Congresso Nacional consegue fazer as leis e, ao mesmo tempo, burlá-las.

Conforme Arroyo, Marx elabora uma teoria da produção/formação de seres humanos que não parte da escola, nem se propõe a reformá-la, mas tem no trabalho e na práxis social os princípios educativos por excelência. Com base na teoria marxiana, Arroyo afirma que a divisão social do trabalho é produto de relações históricas de força às quais os trabalhadores são sujeitos, mas também que, nessas relações, os sujeitos se formam e se educam. Há, portanto, uma politecnia e uma omnilateralidade presentes na fábrica ${ }^{13}$.

Arroyo (1989) analisa as possíveis relações entre trabalho escolar e LDB, começando por afirmar que uma nova lei não é uma questão de princípios, por mais progressistas que sejam, embora reconheça sua importância. Numa sociedade capitalista, a elaboração de uma lei é sempre uma questão de caráter prático-político em que forças antagônicas se defrontam num determinado contexto histórico. Critica, ainda, a delimitação do papel da escola em termos de um 'dever ser', sem uma referência na prática social, uma vez que a relação entre o trabalho e a educação, na lei, constitui-se numa proposta político-programática.

Quando Marx defende a união do ensino com o trabalho produtivo, ele o faz em circunstâncias concretas de exploração do trabalho infantil, e suas propostas fazem parte de programas político-partidários, numa perspectiva de diretrizes a serem seguidas após a tomada do poder em um processo revolucionário (Marx, 1977 e 1982). Tais programas, como enfatizado também por Nosella na análise da obra de Gramsci, respondem a questões colocadas pela conjuntura de uma época em que era muito forte a percepção, por parte do movimento operário europeu, da possibilidade de uma revolução socialista. São, portanto, fatos concretos que exigem soluções concretas, enunciadas a partir de concepções político-partidárias, também estruturadas e refletidas nas lutas concretas contra a exploração dos trabalhadores pelo capital. Daí o fato de Marx preocupar-se mais com a regulamentação do trabalho do que com a definição dos conteúdos politécnicos nos currículos escolares, conclui Arroyo (1989).

Dando continuidade a este debate, para a $12^{\text {a }}$ Reunião Anual da Anped, realizada em maio de 1989, foram sintetizadas as discussões sobre 
"O trabalho como princípio educativo e a educação politécnica", das quais destacamos o alerta de que "o espaço que temos hoje no Brasil é o espaço das contradições, da luta para a transformação dessas relações na sociedade e na escola. Sem essa clareza, corremos o risco de derivar para posições iluministas e idealistas" (Anped, 1989, p. 4).

A culminância deste debate sobre o trabalho como princípio educativo de uma escola unitária, visando a uma formação omnilateral, ocorreu na Universidade de Brasília (UnB), entre $1^{\circ}$ e 4 de junho de 1989, durante a greve nacional das Instituições Federais de Ensino Superior (Ifes), quando foi realizado o I Seminário Nacional de Educação, promovido pelo Sindicato Nacional dos Docentes das Instituições de Ensino Superior (AndesSN), Federação das Associações de Funcionários das Universidades Brasileiras (Fasubra), Confederação Nacional dos Trabalhadores da Educação (CNTE) e União Nacional dos Estudantes (UNE). Neste seminário, em que os pesquisadores acima mencionados expuseram suas concepções e do qual esta autora participou como delegada da Associação dos Docentes da Universidade Federal do Amazonas (Adua), foram sistematizadas as propostas do movimento docente e discente à nova LDB. No Projeto de Lei de Diretrizes e Bases da Educação Nacional elaborado pela Andes (Andes-SN, 1991), não consta a educação profissional, mas no título VI, “Da educação básica", o artigo 31 estabelece que esta modalidade de educação deverá estar "centrada no trabalho como mediador das relações do homem com a natureza e com os outros homens". Analisando o texto aprovado na Comissão de Educação da Câmara dos Deputados, Moraes (1991, p. 41, grifo do autor) diz que, "no inciso XI, foi rejeitada a garantia de uma educação unitária básica para todos os cidadãos; preferiu-se assegurar uma 'educação básica comum'"”. Florestan Fernandes (1991, p. 36), na época deputado federal pelo Partido dos Trabalhadores (PT), também analisa conquistas e perdas no que chama de "conciliação aberta" sobre as diretrizes e bases e aconselha a "refletir muito sobre os caminhos a seguir e os adversários a arrostar". Antecipa, assim, o caminho do projeto popular de LDB, desfigurado com emendas de todo tipo e derrotado pelo projeto do senador Darcy Ribeiro.

Na perspectiva da história em movimento, com a qual temos trabalhado, assinalamos que a abertura do debate sobre trabalho-educação deu-se com uma greve, a primeira a desafiar a ditadura militar, e, paralelamente, com a realização do I Seminário da Educação Brasileira, ambos em São Paulo, em 1978. Não por acaso, o fechamento das propostas do projeto popular de LDB também foi feito durante uma greve. Em 1989, as universidades federais realizaram uma greve nacional coordenada pela Andes/SN, que organizou o I Seminário Nacional de Educação, em Brasília, onde se encontrava o comando de greve e está sediado o Congresso Nacional, para onde seriam 
encaminhadas as propostas. Destaco, levando em conta os propósitos do artigo, que o trabalho é o eixo de sustentação daquele projeto.

Ressaltamos a contribuição da Anped através dos pesquisadores vinculados ao GT "Trabalho e educação" que já vinham produzindo estudos sobre o tema, sem ignorar os pesquisadores dos demais grupos de trabalho, que também contribuíram com análises e propostas, nas suas áreas de pesquisa, ao projeto popular de LDB. Este projeto, deformado pelas emendas dos parlamentares vinculados ao ensino privado, mas, mesmo assim, proveniente de ampla participação popular, foi aprovado na Câmara Federal e passou ao Senado, onde, através de manobras políticas, foi substituído pelo Projeto Darcy Ribeiro, como tem sido chamada a LDB n ${ }^{\circ}$ 9.394/96.

O alargamento da concepção de educação para além dos espaços formais de ensino e a vinculação do trabalho à educação escolar provenientes dos debates e das propostas contidas no projeto popular, aparecem na nova $\mathrm{LDB}^{14}$, o que, num primeiro momento, pode evidenciar a força dos movimentos sociais de que provêm aqueles debates e propostas. Veremos, ao analisar as políticas públicas para a educação profissional e tecnológica, que a questão não é tão simples quanto parece.

Concluindo nossa análise sobre o trabalho como princípio educativo no projeto popular de LDB, a nova lei $\mathrm{n}^{\circ}$ 9.394/96 abriu espaço para a imposição do decreto-lei $\mathrm{n}^{\circ} 2.208 / 97$, que de forma disfarçada reapresentou e validou o projeto de lei $n^{\circ} 1.603 / 97$. Este fora duramente rechaçado pelas organizações docentes ligadas às escolas técnicas federais, principalmente por separar a educação básica da educação profissional, aprofundando o caráter dual da educação brasileira, e por pretender destruir o acúmulo historicamente construído de qualidade da formação humana articulada à formação técnica, que detinham e ainda detêm aquelas escolas.

\section{Políticas públicas em trabalho, educação e tecnologia: projetos em disputa}

A intensa discussão iniciada no final da década de 1970, tendo as camadas populares como sujeitos da educação pública e ancorada nos movimentos sociais populares, com a derrota do projeto popular de LDB no Congresso Nacional deixa claros os interesses de classe constitutivos da relação entre trabalho, educação e tecnologia. Estes interesses estarão mais visíveis na formulação de políticas para esta área, conforme veremos. A LDB do governo Fernando Henrique Cardoso (FHC) legitima o decreto $\mathrm{n}^{\circ} 2.208 / 97$, impondo uma reformulação do ensino médio e técnico em sentido contrário ao do trabalho como princípio educativo de uma formação omnilateral, proposto pelos pesquisadores ao longo de mais de 20 anos e por educadores de todo o país, organizados no Fórum Nacional em Defesa da Escola Pública. No 
governo Luiz Inácio Lula da Silva, o Ministério da Educação (MEC) critica o atrelamento da legislação educacional às exigências dos organismos multilaterais, como o Fundo Monetário Internacional (FMI), Banco Internacional para Reconstrução e Desenvolvimento (Bird) e o Banco Interamericano de Desenvolvimento (BID) (Ribeiro, 2005), ao afirmar que “o 'novo' consistiu na adequação direta dos conceitos e objetivos educacionais às necessidades econômicas" (MEC, 2004, p. 3). Quanto às concepções de educação profissional e tecnológica, o documento "Políticas públicas para a educação profissional e tecnológica", do MEC, registra:

“O entendimento preliminar da educação tecnológica provém de uma concepção ampla e profunda da educação, que preencha os estágios formativos, construídos nos processos básicos dos valores inerentes ao ser humano, privilegiando as vertentes da tecnologia, admitindo o trabalho como categoria de saber e de produção, que se organiza de maneira inovadora, provocando mudanças socioeconômicas" (MEC, 2004, p. 14).

Nas concepções é onde, nos parece, deveriam sediar-se as definições orientadoras da formulação de políticas para uma determinada área, a serem materializadas em práticas. Quando atentamos para o texto da proposta de políticas de educação profissional e tecnológica, observamos que ele se distancia bastante das atuais políticas formuladas e implementadas para esta modalidade de educação. Se o entendimento preliminar da educação tecnológica compreende uma "concepção ampla e profunda da educação" que articula a formação humana ao trabalho como produtor de bens e conhecimentos - no que se aproxima do projeto popular de LDB -, as leis e a distribuição dos recursos para a mencionada área contrariam aquele entendimento e se contrapõem ao projeto popular, conforme veremos. O documento também registra que a formulação das políticas para a educação profissional e tecnológica acontece dentro de "um campo de forças atuante na estrutura social", impondo limites que decorrem da divergência entre os interesses representativos dos setores empresariais, e as demandas de educação básica e profissional dos segmentos que representam os trabalhadores, o que confirma as análises dos autores sobre a relação trabalho-educação na LDB.

O documento analisado, "Políticas públicas para a educação profissional e tecnológica" (MEC, 2004), nas páginas 27 a 29, traz um quadro descritivo geral do número de sujeitos que justificam a formulação de uma política para a educação profissional e tecnológica. O quadro registra que 22,2 milhões de brasileiros são analfabetos e cerca de $80 \%$ da população não concluiu a educação básica. É como se estes dados fossem decorrentes de fatores naturais ou, quem sabe, dos 'qualificativos pejorativos' que ideologicamente têm sido atribuídos à mistura de raças que constitui o povo 
brasileiro. Sem uma análise estrutural que situe as condições históricas e as determinações econômicas nas quais se configuram as atuais possibilidades e formas de trabalho e, mais concretamente, os limites impostos pela correlação de forças entre as classes - que determinam, por sua vez, os limites do possível para a educação dos trabalhadores brasileiros -, há o risco de se naturalizarem os dados que sustentam o delineamento das políticas para a educação profissional e tecnológica.

No mesmo documento, a importância da legislação básica da educação profissional e tecnológica é justificada por sua relação com o desenvolvimento econômico e o avanço tecnológico. Essa importância pode ser percebida na afirmação de que a educação profissional e tecnológica é cada vez mais

“(...) estratégica para o desenvolvimento socioeconômico do país, principalmente se considerarmos o atraso tecnológico de diversos setores da economia, a necessidade de diminuição das desigualdades regionais e a elevação do nível de escolaridade e de capacitação tecnológica da população" (MEC, 2005b, p. 8).

Todavia, a legislação e os programas que estão sendo implementados na área de educação profissional e tecnológica evidenciam enormes contradições entre os textos dos documentos destinados à divulgação externa e as ações através das quais as políticas se materializam. A classe proprietária dos meios de produção e de comunicação e dos recursos financeiros tem sido vitoriosa, principalmente, ao apropriar-se de recursos do Estado e ao manipulá-los segundo seus interesses, exercendo domínio sobre o conjunto das atividades humanas, o que significa "uma subsunção da vida dos trabalhadores ao capital"' (Tumolo, 2003).

Hoje, a riqueza provém, em grande parte, do deslocamento do capital acumulado por meio da produção de bens, conhecimentos e serviços, para aplicação no setor financeiro, movendo-se ao sabor do jogo do mercado de ações. Alimenta, assim, uma bolha especulativa em caráter global, em que a riqueza se multiplica via computador ${ }^{15}$. A educação de modo geral e a educação profissional e tecnológica em especial ficam à mercê dos humores dos sujeitos representativos do capital que investem neste mercado (Silva Jr., 2002). Na seqüência, traremos alguns exemplos que corroboram o que temos afirmado.

O decreto $\mathrm{n}^{\circ} 2.208 / 97$, do governo FHC, foi substituído pelo decreto $\mathrm{n}^{\circ}$ 5.154/04, no governo Lula. Esta 'reforma da reforma' expressa a força dos interesses de classe que se confrontam na formulação e implementação das políticas educacionais, sobretudo daquelas em que a relação entre trabalho e educação é mais evidente. Esses interesses tanto atravessam, numa ponta, a formulação das leis e a distribuição dos recursos, quanto se expressam, na 
outra ponta, nas práticas através das quais as políticas são implementadas. Dependendo da correlação de forças, a lei escrita pode apagar, do texto e da história, as propostas provenientes das camadas populares, como ocorreu com a LDB Darcy Ribeiro. Porém, ao serem traduzidas em práticas nas grades curriculares, disciplinas e conteúdos, outras forças que representam as camadas populares - porque estas adentram a escola pública - podem frustrar o texto da lei e retomar, embora com imensa dificuldade, algumas das propostas que a lei ignorou.

Para Rodrigues (2005), o decreto $\mathrm{n}^{\circ} 5.154 / 2004$ avançou 40 anos. Da aproximação que o decreto $\mathrm{n}^{\circ}$ 2.208/97 mantinha com “as leis orgânicas de ensino" decretadas, em 1942, pelo ministro Capanema, do Estado Novo, a atual reforma desloca-se para as proximidades da lei $\mathrm{n}^{\circ} 7.044 / 82$, do regime militar. Esta retirava o caráter compulsório da profissionalização no ensino de segundo grau, imposto pela lei $\mathrm{n}^{\circ}$ 5.692/71. Daí o avanço de 40 anos apontado pelo autor. Ressalte-se que, em ambos os casos, são leis produzidas por ditaduras: civil no primeiro caso e militar no segundo. De todo modo, reescreve-se a lei, também sob forma de decreto. Por um lado, permite a integração entre ensino médio e técnico, o que se tornou difícil em muitas escolas, que depois de muita pressão do MEC e de conflitos internos, efetuaram as mudanças. Por outro, mantém-se a essência da lei, que é sua adaptabilidade às demandas do capital para a formação de um trabalhador flexível e a baixo custo.

Pesquisadores vinculados ao GT "Trabalho e educação" fizeram uma análise, através da lista de discussão do grupo, do parecer do CNE/CEB $\mathrm{n}^{\circ} 39 / 2004$, aprovado em 8 de dezembro de 2004, que dispõe sobre a aplicação do decreto $n^{\circ} 5.154 / 2004$. Em sua análise, denunciam o que consideram continuísmo do atual governo em relação à política do governo anterior para a educação profissional e tecnológica. Privilegia-se a instrução individual no lugar de uma formação voltada para os interesses coletivos; objetiva-se a flexibilidade para adaptar-se às incertezas da falta ou da mudança constante de emprego; tem-se por meta uma empregabilidade vazia, ou pelo menos bastante restrita quanto à possibilidade de realização.

O GT "Política e educação" do Andes-SN desenvolveu estudos sobre políticas para a educação profissional e tecnológica, uma vez que, entre associados deste sindicato, há pesquisadores vinculados aos Centros Federais de Educação Tecnológica (Cefet). Este GT reconhece que o decreto $\mathrm{n}^{\circ}$ 5.154/2004 teve a participação das entidades que representam professores e pesquisadores da área, mas que sua aprovação deu-se em um processo eivado de conflitos, decorrentes de interesses antagônicos que se confrontavam na definição da lei. Assim, ainda que aquele decreto abre espaço para a integração entre ensino médio e ensino técnico, ele continua a admitir "a desvinculação entre a formação geral e profissional", que expressa a 
histórica dualidade estrutural da educação brasileira, mais visível quando se estreitam os vínculos entre trabalho e educação (Andes-SN, 2005, p. 12). Como participantes efetivos do processo de revogação do decreto $n^{\circ}$ 2.208/1997 e de construção do decreto $n^{\circ}$ 5.154/2004, Frigotto, Ciavatta e Ramos elaboram o registro histórico deste processo no texto "A gênese do decreto 5.154/2004: um debate no contexto controverso da democracia restrita" (2005). Os autores confirmam referências anteriormente feitas à trajetória do projeto popular de LDB e à discussão sobre politecnia e tecnologia presente nas obras de Machado (1989b) e Nosella (1989), retomada por Saviani (2003). Manifestam sua preocupação com a política de defesa de uma lei orgânica da educação profissional por parte da Secretaria de Educação Profissional e Tecnológica (Setec), o que significaria um retrocesso, conforme já foi apontado por Rodrigues (2005). E, apesar de evidenciarem, no conteúdo do decreto $\mathrm{n}^{\circ} 5.154 / 2004$, “a persistência de forças conservadoras no manejo do poder de manutenção de seus interesses" (Frigotto, Ciavatta e Ramos, 2005, p. 52), entend em que este documento, ao garantir a integração do ensino médio ao ensino técnico, abre espaço para uma base unitária de formação geral como "condição necessária para se fazer a 'travessia' para uma nova realidade" (p. 43).

Na seqüência, traremos à análise alguns projetos e programas pontuais que evidenciam a ressignificação do artigo 1, principalmente do parágrafo $2^{\circ}$ da LDB, anteriormente citados. Iniciaremos pelo Escola de Fábrica, produzido e implementado em um processo de fortes discussões que tiveram início em outubro de 2004, envolvendo setores representativos do ensino público e do ensino privado, com o Governo Federal. Pesquisa efetuada no sítio do MEC, apresenta o Escola de Fábrica como programa e como projeto. Como programa, é uma "iniciativa do Governo Federal, executado através do Ministério da Educação e da Secretaria de Educação Profissional e Tecnológica (Setec)". Está direcionado à inserção de “jovens de baixa renda no mercado de trabalho através de cursos de iniciação profissional em unidades formadoras no próprio ambiente das empresas, gerando renda e inclusão social". Entre suas missões destacamos as de "promover a inclusão social de jovens de baixa renda através da iniciação profissional" e "apoiar ações de responsabilidade social nos setores produtivos". Enquanto projeto, sua regulamentação teve início como medida provisória $\mathrm{n}^{\circ} 251$ de 14/06/2005, passando à resolução CD/FNDE $n^{\circ} 31$, de 22/07/2005, tornando-se lei $n^{\circ}$ 11.180 de 23/09/2005 que institui o projeto Escola de Fábrica com a "finalidade de prover formação inicial e continuada a jovens de baixa renda que atendam aos requisitos previstos no art. $2^{\circ}$ desta lei".

Retomando-se o documento "Políticas públicas para a educação profissional e tecnológica" verifica-se que a compreensão da educação tecnológica 
“provém de uma concepção ampla e profunda da educação que preencha os estágios formativos construídos nos processos básicos dos valores inerentes ao ser humano, privilegiando as vertentes da tecnologia, admitindo o trabalho como categoria de saber e de produção, que se organiza de maneira inovadora, provocando mudanças socioeconômicas" (MEC, 2004, p. 14).

Comparando-se, então, a "concepção ampla e profunda da educação", apontada nesse documento, com a legislação resultante, considerando seus estágios como programa e projeto, e suas regulamentações como medida provisória, resolução e lei, acima enunciadas, observa-se um distanciamento entre essa concepção e o que foi legislado para as populações de baixa renda, que já se encontram com defasagem de educação escolar.

O conflito na elaboração das leis que regulamentam a política educacional, mormente a de educação profissional, já estava reconhecido pelo documento (MEC, 2004, p. 1) ao registrar a existência de um "campo de forças atuante" dentro do sistema educativo. É nessa ótica, a do conflito, que podemos inferir a força dos setores representativos do capital que buscam anular a qualificação como relação social construída historicamente (Ramos, 2001 e 2002; Ferretti, 2004; Ribeiro, 2002). E, nessa mesma lógica, se substitui a qualificação social pela "pedagogia das competências" individuais e voláteis, que demandam menos tempo e menor custo para sua incorporação. Desse modo, o jovem trabalhador fica 'liberto' de vínculos associativos e munido de "competências básicas" para negociar, no mercado, uma das raras vagas disponíveis ou para continuar, através da "formação continuada", a busca por novas "competências", cumprindo o círculo vicioso formação, mercado, formação.

A idéia do Projeto Escola de Fábrica já estava implícita no decreto $\mathrm{n}^{\circ}$ 2.208/97, como denuncia o Sindicato dos Professores do Cefet do Paraná (GPTE-Sindocefet-PR) ao afirmar que coube à Setec "requentá-la, sofisticála e colocar-se como agência financiadora", o que, mais uma vez, demonstra não haver diferenças essenciais entre aquele decreto e sua reforma no governo atual. A mesma entidade sindical conclui a respeito do Projeto Escola de Fábrica:

“A implementação dessas escolas representará o uso privado de recursos públicos, além de atender às especificidades de determinadas empresas, transformando a educação profissional num mero treinamento ou adestramento para o desenvolvimento de uma atividade profissional específica" (GPTE-Sindocefet-PR, 2005, p. 40).

Rummert (2005) traça um paralelo entre o Projeto Escola de Fábrica e a legislação educacional brasileira do século XIX destinada a crianças pobres. A análise comparativa feita pela autora confirma, mais uma vez, o retrocesso 
da legislação e os interesses de classe que a definem. Questionando o orçamento previsto para este projeto, afirma:

“Afinal, no caso específico do Escola de Fábrica, é a isso que se destina o item orçamentário Implantação e Recuperação de Centros Escolares de Educação Profissional. Deslocar mesmo que pequena parte de tais recursos para favorecer a criação de espaços de formação sistematizada, dentro das próprias empresas segundo os interesses destas, é, no mínimo, um procedimento equivocado" (Rummert, 2005, p. 316).

Na mesma linha do Projeto Escola de Fábrica, encontra-se o Programa Nacional de Inclusão de Jovens (ProJovem), objeto de uma sessão especial na $28^{a}$ Reunião da Anped com o título "Possibilidades e impasses para a integração de políticas educacionais e sociais: o caso do ProJovem" ${ }^{16}$. Na ementa desta sessão especial, distribuída entre os pesquisadores participantes, está registrado que:

“O ProJovem - Programa Nacional de Inclusão de Jovens integra a Política Nacional de Juventude do Governo Federal. Iniciou-se em 2005, com orçamento de 300 milhões de reais. (...) O Programa é voltado para jovens moradores das capitais, com idade entre 18 e 24 anos, que estejam fora do mercado formal de trabalho e que, tendo passado pela $4^{a}$ série, não tenham concluído a $8^{a}$ série do ensino fundamental".

Participando como debatedora na referida sessão, Rummert, além de desvelar as fragilidades teórico-metodológicas do ProJovem, aponta o fato de o programa predeterminar o futuro dos jovens pobres, não lhes oferecendo condições que aliem formação humana e trabalho produtivo, obrigando-os, ao invés disso, a conformarem-se com uma ordem social que não lhes oferece nem oportunidades de trabalho digno, nem educação condizente com seu direito de cidadania (Ribeiro e Lima Filho, 2005).

A análise do ProJovem feita por Rummert na ocasião confirma o que já dissemos a respeito da proposta de política para a educação profissional e tecnológica. Filiado a esta, o ProJovem também naturaliza a condição de ser jovem pobre na atual sociedade brasileira e não questiona a pulverização dos escassos recursos entre secretarias estaduais, municipais, organizações não-governamentais, terceiro setor e empresas para a execução de programas pontuais e focalizados. Além do mais, evidencia a interferência dos organismos multilaterais, principalmente do Banco Mundial e do BID, na definição das políticas para a educação da juventude brasileira.

Com a mesma concepção que orienta o Projeto Escola de Fábrica e o ProJovem, o MEC está propondo a criação de um Sistema Nacional de Certificação Profissional. Esta iniciativa refere-se à regulamentação do artigo 41 da 
LDB, o que foi feito através da portaria no 646 de 14 de maio de 1997 (MEC, 2001, p. 32). Na minuta da proposta, que ainda se encontra em processo de discussão, a certificação é assim concebida:

“A certificação profissional é o processo negociado pelas representações dos setores sociais e regulado pelo Estado, pelo qual se identifica, avalia e valida formalmente os conhecimentos, saberes, competências, habilidades e aptidões profissionais desenvolvidas em programas educacionais ou na experiência de trabalho, com o objetivo de promover o acesso, permanência e progressão no mundo do trabalho e o prosseguimento ou conclusão de estudos" (Comissão Interministerial de Certificação Profissional, 2005, p. 2).

Na proposta de certificação profissional apresentada pela Comissão Interministerial, é possível identificar contradições que sinalizam tanto para avanços de demandas sociais quanto para um retrocesso na medida em que podem ser visualizados interesses conservadores que fortalecem a dualidade estrutural da educação brasileira. A proposta avança no sentido de reconhecer a legitimidade dos saberes acumulados nas experiências de trabalho e nas práticas sociais, o que, de certa forma, foi conquistado no artigo 1 da lei $n^{\circ} 9.394 / 96$ e, principalmente, em seu parágrafo $2^{\circ}$, que já comentamos. Mas, ao validar esses saberes do trabalho e da experiência, conferindo-lhes certificação formal, de certo modo, a proposta de certificação profissional justifica a sonegação da educação como um direito que o Estado deve assegurar aos cidadãos e cidadãs, pela oferta de condições de ingresso e permanência na escola na idade prevista em lei. Ela também é conservadora porque reafirma uma concepção de educação fragmentada para os trabalhadores, "afastando-se de uma perspectiva de educação omnilateral, que considere os saberes tácitos do trabalho, mas que apenas parta deles para oferecer uma formação geral e tecnológica condizente com as descobertas científicas e tecnológicas atuais" (Ribeiro, 2005, p. 11).

A certificação dos saberes da experiência é, de fato, o reconhecimento de que o trabalho tem uma dimensão educativa de produção de conhecimento. A partir de outro ângulo, retomando as críticas de Lima Filho (2003) sobre a "desescolarização da escola" e de Freitas (2002) sobre "a internalização da exclusão", a valorização desta certificação também pode significar um argumento para esvaziar o papel da escola como instituição historicamente responsável pela transmissão do conhecimento socialmente produzido, que, no resgate anteriormente feito do debate sobre trabalho-educação, seria uma educação omnilateral, agregando elementos da formação humanística aos elementos peculiares a uma formação científica e, ao mesmo tempo, politécnica e tecnológica. 
A possibilidade aberta aos Cefets pela LDB $n^{\circ}$ 9.394/96 de ofertarem ensino superior para a formação do tecnólogo ou a transformação de alguns destes centros em universidades justificou a iniciativa do MEC de iniciar um debate, em nível nacional, para construir uma política nacional de formação dos formadores para a educação profissional e tecnológica. Com essa finalidade, foram realizados seminários regionais para diagnosticar a situação da educação profissional e tecnológica nas diferentes regiões, que culminaram com um Seminário Interno de Discussão da Proposta Metodológica para a Construção da Política de Formação de Profissionais da Educação Profissional Tecnológica, no qual o GT “Trabalho e educação” esteve representado.

Documentos dos seminários regionais destacam que as iniciativas de capacitação docente para a educação profissional e tecnológica "vêm assinadas pela alcunha de emergenciais, fragmentárias, pouco intensivas e com caráter bastante conservador" (Pereira, 2004, p. 4).

O Cefet/RN apontou como desafios "o financiamento, as discrepâncias entre os diversos grupos destinatários, as exigências do mundo do trabalho e a responsabilidade com os egressos e com a sociedade". A abordagem desses desafios culmina com a seguinte questão: "podemos tratar de um marco de regulação para a EPT [educação profissional e tecnológica] sem discutir o desenvolvimento econômico do país?" (Moura, 2004, quadro 3).

Durante o Seminário Interno organizado pelo MEC, foi apresentado um quadro nacional que demonstra as disparidades regionais e a fragmentação das experiências de formação dos profissionais da educação profissional e tecnológica. Porém, esta descrição, como as demais que têm fundamentado as políticas para a área, naturalizou os dados por não se fazer acompanhar de uma análise estrutural e conjuntural que apontasse as contradições e, a partir delas, os desafios colocados à educação profissional e tecnológica e à formação de seus formadores. Se o contexto é de interferência dos organismos multilaterais na formulação das políticas para a área e se o setor privado detém $70 \%$ dos recursos, qual a margem de manobra para o setor público formular políticas que venham ao encontro de uma educação profissional e tecnológica com caráter de formação humana omnilateral?

Sobre a criação de licenciaturas destinadas à formação de professores para a educação profissional e tecnológica, manifestaram-se dois pesquisadores do GT "Trabalho e educação". Paolo Nosella acredita que uma licenciatura, independentemente da área, precisa abarcar em profundidade a formação científica, articulada à formação humanística. A tendência à multiplicação das licenciaturas aponta, segundo o autor, para a existência de uma crise social de desintegração da unidade humana, porque as pessoas estão sendo coagidas a atender às contínuas exigências de mudanças por parte do mercado, dos produtos e dos profissionais, o que corresponde a uma educação marcada pela superficialidade e pela fragmentação. Marise 
Ramos (2005b) também contribuiu para este debate, colocando no grupo de discussão do GT algumas reflexões. Nelas, a autora se pergunta se a formação dos profissionais para a educação profissional e tecnológica deveria ser feita em separado da formação de professores das disciplinas da educação básica. Para Ramos, a formação dos formadores da educação profissional e tecnológica deveria ser efetuada em nível de pós-graduação.

Uma abordagem sobre políticas públicas em trabalho, educação e tecnologia ficaria incompleta se não nos referíssemos ao financiamento destas políticas. Buscando elementos para a análise é que nos damos conta da escassez de estudos que abordem a aplicação dos recursos públicos para a educação básica, profissional e tecnológica. A maior parte dos estudos neste campo está voltada para o financiamento do ensino superior.

Ao analisar 'a reforma da reforma' ou a substituição do decreto $\mathrm{n}^{\circ} 2.208 / 96$ por um novo decreto, o $n^{\circ} 5.154 / 2004$, Kuenzer (2005) confirma a denúncia de inúmeros autores sobre o atrelamento às determinações e definições dos organismos nacionais e internacionais com relação às políticas para o ensino médio e para a educação profissional e tecnológica. Segundo esta autora, não havia necessidade de um novo decreto apenas para incluir a possibilidade de integração entre ensino médio e profissional de nível técnico, entre outras modalidades de educação profissional e tecnológica, ou para definir a duração deste ensino integrado. O decreto $\mathrm{n}^{0} 5.154 / 2004$, do atual governo, que, na essência, não altera o anterior, pode ser entendido, entre outras reflexões críticas, como "manutenção do verdadeiro balcão de negócios em que se transformaram as instituições públicas e privadas de educação profissional", que deixam de fora a maioria da população brasileira, ou seja, homens e mulheres que sobrevivem do seu trabalho (Kuenzer, 2005, p. 3).

A abordagem, ainda que rápida, do financiamento como sustentáculo das políticas públicas para a educação profissional e tecnológica exige retomar o modelo adotado pelo governo anterior, ou seja, o Programa de Expansão da Educação Profissional (Proep). Na gestão do ministro Cristóvam Buarque, já no governo Luiz Inácio Lula da Silva, este programa estava sendo, aos poucos, desacelerado, quando deixaram de ser assinados muitos projetos com a justificativa da falta de recursos. O programa foi, no entanto, retomado e reforçado durante a curta gestão de Tarso Genro (Grabowski, 2005), tendo continuidade na gestão do atual ministro Fernando Haddad.

Portanto, o Proep, cuja concepção e financiamento têm a participação do Banco Mundial e do BID, significa a manutenção e até a ampliação do endividamento externo, com a finalidade de fornecer recursos financeiros para a transformação, construção e reforma dos Centros Federais de Educação Tecnológica, das Escolas Técnicas Federais e das Escolas Agrotécnicas Federais e para a construção de novas unidades. Os recursos do MEC/BID para o período de 1997 a 2003 giravam em torno de 500 milhões de dólares. 
Desses recursos, 40\% eram destinados às instituições públicas da rede federal e das redes estaduais e $60 \%$, para o chamado eufemisticamente de 'setor comunitário', que abrange as escolas da iniciativa privada.

Analisando o Proep, Lima Filho (2002) desmascara o critério econômico que se sobrepõe à formação humana omnilateral, ao separar o ensino médio e a educação profissional de nível técnico e ao diminuir, em cada uma destas modalidades de ensino, o tempo destinado à formação, efetuando o enxugamento das grades curriculares. Para o autor, "o verbo 'adestrar', utilizado nos termos do referido contrato com o BID, em relação aos objetivos para com a clientela, é revelador da natureza da educação profissional que a ela se pretende imputar" (Lima Filho, 2002, p. 278). A integração ensino médio e técnico, incluída entre outras possibilidades de educação profissional, mantém esta lógica da redução do tempo e da carga horária destinada à formação.

A educação profissional e tecnológica vem sendo financiada por três grandes fontes e programas. Os recursos do Fundo de Amparo ao Trabalhador (FAT) sustentaram o Plano Nacional de Formação Profissional (Planfor), do governo anterior, e hoje sustentam o Plano Nacional de Qualificação (PQN). Já os recursos do MEC, FAT e BID sustentam o Proep, gerenciado pela Setec. Por sua vez, os recursos públicos recolhidos pelas empresas, que sustentam o Sistema $S^{17}$, são geridos exclusivamente por meios empresariais privados, o que tem gerando abundantes críticas por parte de professores e estudantes dos centros e universidades federais de educação tecnológica.

Na proposta de política pública para a educação profissional e tecnológica, o governo atual tece críticas ao anterior, incluindo nelas o Planfor, como já vimos. Mesmo assim, no que concerne à distribuição dos recursos para a política pública de educação profissional e tecnológica, uma mudança na

"relação público-privado só poderá ser conferida na medida em que se efetuem mudanças efetivas na destinação dos recursos públicos e na conduta política diante dos representantes do capital e dos setores sociais que defendem o privatismo na educação" (Ramos, 2005a, p. 52).

A forma como os recursos são distribuídos e aplicados entre instituições públicas e privadas, a proporção desses recursos em relação à produção da riqueza social no país e, por fim, o montante destes recursos para a educação, se comparado ao destinado ao pagamento da dívida externa, revelam tanto os sujeitos coletivos que os definem, quanto a lógica do financiamento para a reprodução da força de trabalho. Na atual correlação de forças, a reprodução da força de trabalho é determinada pelas condições impostas pelo capital, que fabrica, ininterruptamente, força de traba- 
lho obsoleta, acumulada em imenso exército industrial, agrícola, comercial e de serviços, que já não se trata de uma reserva, mas de mercadorias humanas produzidas em série pelo capital e destinadas ao lixo, conforme denuncia Castel (1998).

Até o momento, analisando a direção dos financiamentos e a continuidade das agências internacionais com direito à interferência na definição das políticas para a educação pública, evidencia-se, neste governo, a manutenção do critério econômico e da postura neoliberal adotada pelo governo anterior, privilegiando o custo-aluno sobre a formação humana, o que se concretiza em uma política para a educação profissional e tecnológica baseada no adestramento de uma força de trabalho destinada a se tornar mercadoria descartável.

O resgate da história em movimento revela uma correlação de forças desfavorável à classe trabalhadora, impedindo-a de definir políticas públicas em trabalho, educação e tecnologia tendo por referência a "escola unitária que supere o dualismo da organização social brasileira, com conseqüências para a organização do sistema educacional" (Frigotto e Ciavatta, 2003, p. 120). No mesmo processo, aponta para a necessidade de se prestar atenção nas alternativas de trabalho cooperado e autogestionário que os trabalhadores criam para sobreviver e que estão a demandar estratégias autônomas de formação e de organização cooperativas que possam fortalecer as iniciativas destes trabalhadores e trabalhadoras.

\section{Notas}

${ }^{1}$ Professora do Programa de Pós-Graduação em Educação da Faculdade de Educação da Universidade Federal do Rio Grande do Sul. Líder do grupo de pesquisa Trabalho, Movimentos Sociais e Educação. Pesquisadora com apoio do CNPq e da FAPERGS. Coordenadora do GT “Trabalho e Educação" da Anped. <maribe@adufrgs.ufrgs.br>

2 A autora foi secretária estadual para o Amazonas na Central Única dos Trabalhadores (CUT), entre 1986 e 1987, tendo atuado também na Associação dos Docentes da Universidade do Amazonas (Adua) e na Associação Nacional dos Docentes do Ensino Superior, depois transformada em sindicato (Andes/SN).

${ }^{3}$ O I Seminário de Educação Brasileira, realizado entre 20 e 22 de novembro de 1978, em Campinas, consolida a iniciativa de criação da Revista Educação \& Sociedade "como um vínculo à disposição de educadores e professores na luta pela organização de sua categoria" (Educação \& Sociedade, 1979, p. 3). Este seminário ocorre durante a greve geral dos metalúrgicos de São Paulo, que foi deflagrada em 30 de outubro do mesmo ano - a primeira da categoria desde o golpe militar de 1964 - e reuniu 30 mil pessoas nas ruas para votar a continuidade da greve (Giannotti, s/d, p. 28). 
4 A expressão 'camadas populares' refere-se à categoria 'classe' em seu sentido heurístico, associado à luta de classes (Thompson, 1984). Esta expressão é atravessada pela contradição capital versus trabalho e, portanto, carregada de historicidade. Nos anos 80, no contexto de retomada das lutas sociais lideradas pelos operários metalúrgicos, a categoria 'classe(s) trabalhadora(s)' (Moisés, 1982; Arroyo, 1989), alargando-se para incluir trabalhadores do comércio, dos serviços e até da agricultura, começava a substituir 'classe operária' (Maroni, 1982; De Decca, 1984), relativa aos processos revolucionários do século XIX e décadas iniciais do século XX. Nos anos 90, o desemprego estrutural imposto pelo capital, com a introdução de tecnologias intensificadoras do trabalho aos processos produtivos, recoloca a discussão sobre a categoria 'classe operária' e/ou 'trabalhadora', que já não encontra trabalho sob a forma de emprego assalariado. Para apreender essa nova realidade dos trabalhadores, Ricardo Antunes (1998) formula a categoria "classe-que-vive-do-trabalho". Embora concordando com as análises deste autor sobre as transformações que ocorrem nos processos de reprodução do capital, acreditamos que a categoria por ele sugerida - classeque-vive-do-trabalho - pode abranger os sujeitos do capital, pois são estes que de fato se apropriam e se alimentam do produto do trabalho, e também da mente e da sensibilidade dos trabalhadores. Por isso justificamos o uso da categoria 'camadas populares'.

${ }^{5}$ Ver conexão entre o senso comum, a religião e a filosofia em Gramsci (1981).

${ }^{6}$ Esta obra foi escrita em 1982, porém foi consultada a 9a edição, de 1988. Em 1981, durante o Seminário de Pesquisa Educacional realizado em Cuiabá, na Universidade Federal do Mato Grosso, assisti à fala da professora Guiomar Namo de Mello, que defendia a primazia da competência técnica sobre o compromisso político, justificando estar na incompetência, principalmente dos professores das classes de alfabetização, a explicação do insucesso das crianças provenientes das camadas populares que não aprendiam a ler.

${ }^{7}$ Uma análise que confronta a qualificação profissional como relação social e as competências como noções filiadas ao funcionalismo e correspondentes aos propósitos do padrão flexível de acumulação que substituiu o taylorismo-fordismo é feita por Ra$\operatorname{mos}(2001)$.

${ }^{8}$ Dermeval Saviani e Guiomar Namo de Mello, que iniciaram, nos anos 80, o debate sobre a escola das camadas populares, tomaram caminhos diversos, que apontam compromissos de classe diversos e, em alguns casos, até conflitantes. No caso do debate em tela, Dermeval Saviani aproxima-se de Guiomar Namo de Mello e tenta fazer uma mediação entre as teses defendidas por esta e os questionamentos feitos por Paolo Nosella (1983) no artigo "O compromisso político como horizonte da competência técnica". O próprio Saviani (1983, p. 111) explica as razões pelas quais toma este caminho no artigo "Competência política e compromisso técnico ou (o pomo da discórdia e o fruto proibido)", afirmando que "Guiomar e Paolo integraram a mesma turma de doutorado em Educação da PUC/SP e ambos tiveram suas teses por mim orientadas".

${ }^{9}$ Este texto também foi publicado em Pedagogia histórico-crítica: primeiras aproximações (Saviani, 1991, p. 31- 69).

${ }^{10}$ Vinte e dois anos após publicar o artigo em que contestou a visão de Mello, Nosella (2005, p. 226) fez uma releitura do debate da década de 1980 sobre a relação entre o compromisso político e a competência técnica, afirmando que o "romantismo político trouxe, felizmente, um inegável saldo positivo para o país e, especificamente, para o campo da educação", enquanto hoje a sociedade aponta questões que exigem um aprofundamento maior da obra de Gramsci, na qual aqueles pensadores brasileiros se inspiravam. 
${ }^{11}$ Neste mesmo ano, Lucília Machado (1989b) publicou os estudos desenvolvidos em seu doutorado, nos quais amplia sua compreensão do que seria a escola unitária.

12 Demos preferência a esta versão em função das valiosas contribuições de Paolo Nosella para a compreensão do contexto em que Gramsci formula suas questões e produz a obra, podendo-se, com isso, relativizá-la ao trazê-la para a realidade brasileira. O Caderno 12 encontra-se, também, em Gramsci (2001).

${ }^{13}$ Nesse texto (Arroyo, 1989), 'fábrica' é um termo que pode significar qualquer forma de organização e gestão dos processos de trabalho - inclusive os da escola - que têm a empresa capitalista como referência.

${ }^{14}$ Ver título 1, artigo 1 da lei $n^{\circ} 9.394 / 96$.

${ }^{15}$ Sobre o deslocamento que se faz do movimento do capital, da produção industrial de massa voltada para o consumo de massa (que caracteriza o taylorismo-fordismo), para o predomínio do comércio, dos serviços, passando a riqueza a ser virtualmente (re)produzida pela especulação financeira (que caracteriza o padrão flexível de acumulação), ver Singer (2003) e Chesnais (2003).

${ }^{16}$ A sessão especial ocorreu em 19 de outubro de 2005, em Caxambu (MG), na sala São Lourenço do Hotel Glória. Foi organizada por Vera Masagão Ribeiro, da ONG Ação Educativa, e teve a participação da coordenadora de formação do ProJovem, do MEC, professora Maria Amélia Zabag, de pesquisadores de alguns GT da Anped, entre eles Sonia Rummert, do GT "Trabalho e Educação".

${ }^{17}$ O Sistema S inclui: Serviço Nacional de Aprendizagem Industrial (Senai), Serviço Nacional de Aprendizagem Comercial (Senac), Serviço Social da Indústria (Sesi), Serviço Social do Comércio (Sesc), Serviço Social de Transporte (Sest), Serviço Nacional de Aprendizagem do Setor Transporte (Senat), Serviço Nacional de Aprendizagem Agrícola (Senar), Serviço Brasileiro de Apoio a Micro e Pequenas Empresas (Sebrae) e Serviço Nacional de Aprendizagem do Cooperativismo (Sescoop).

\section{Referências}

ANDES-SN (Sindicato Nacional dos Docentes das Instituições de Ensino Superior). fev. 1991. Projeto de Lei de Diretrizes e Bases da Educação Nacional. Universidade e Sociedade, n. 1. fev. Brasília. Encarte.

2005. As politicas para a educação profissional e tecnológica. Brasília: FotoArte.

ANPED (Associação Nacional de Pós-Graduação e Pesquisa em Educação). 1989. Lei de Diretrizes e Bases da Educação
Nacional: propostas específicas e subsídios. Boletim Anped, v. 10, n. 1-2, p. 1-108.

2005. As políticas para a educação profissional e tecnológica. Brasília: FotoArte.

ANTUNES, Ricardo. 1998. Adeus ao trabalho? Ensaio sobre as metamorfoses e a centralidade do mundo do trabalho. $5^{\mathrm{a}}$ ed. São Paulo: Cortez; Campinas: Unicamp.

ARROYO, Miguel Gonzalez. 1986. A escola possível é possível? In: ARROYO, Mi- 
guel Gonzalez (org.). Da escola carente à escola possível. São Paulo: Loyola, p. 11-53.

1989. Trabalho, educação escola. Revista de Educação, n. 4, p. 4-12.

BRANDÃO, Carlos Rodrigues (org.). 1980. A questão política da educação popular. São Paulo: Brasiliense.

CASTEL, Robert. 1998. A metamorfose da questão so cial. Petrópolis: Vozes.

CHESNAIS, François. 2003. A 'nova economia': uma conjuntura própria à potência estadunidense. In: CHESNAIS, François et al. Uma nova fase do capitalismo. São Paulo: Xamã; Campinas: Cemarx-IFCH-Unicamp, p. 43-70.

COMISSÃO INTERMINISTERIAL DE CERTIFICAÇÃO PROFISSIONAL. 2005. Sistema Nacional de Certificação Profissional: proposta governamental. Brasília.

DE DECCA, Edgar. 1984. 1930: o silêncio dos vencidos. $2^{a}$ ed. São Paulo: Brasiliense.

EDUCAÇÃO \& SOCIEDADE. 1979. Aos leitores. n. 2. p. 3. Editorial.

FERNANDES, Florestan. 1991. Diretrizes e bases: conciliação aberta. Universidade e Sociedade, n. 1, p. 33-36.

FERRETTI, Celso João. 2004. Considerações sobre a apropriação das noções de qualificação profissional pelos estudos a respeito das relações entre trabalho e educação. Educação \& Sociedade, v. 25, n. 87, p. 401-422.

FREITAS, Luiz Carlos de. 2002. A internalização da exclusão. Educação \& Sociedade, v. 23. n. 80, p.301- 328.

FRIGOTTO, Gaudêncio. 1989. Trabalho, educação e tecnologia: treinamento polivalente ou formação politécnica? Educação \& Realidade, v. 14, n.1, p. 17- 28.

FRIGOTTO, Gaudêncio; CIAVATTA, Maria. 2003. Educação básica no Brasil na década de 1990: subordinação ativa e consentida à lógica de mercado. Educação \& Sociedade, v. 24, n. 82, p. 93-132.

FRIGOTTO, Gaudêncio; CIAVATTA, Maria; RAMOS, Marise. 2005. A gênese do decreto n. 5.154/2004: um debate no contexto controverso da democracia restrita. In: (orgs.). Ensino médio integrado: concepção e contradições.
São Paulo: Cortez; Rio de Janeiro: Editora Fiocruz, p. 21-56.

GADOTTI, Moacir. 1986. Educação e compromisso. $2^{\text {a }}$ ed. Campinas: Papirus.

GIANNOTTI, Vito. s/d. Cem anos de luta da classe operária no Brasil, 1880-1980. São Paulo: In-formar.

GOHN, Maria da Glória. 1992. Movimentos sociais e educação. São Paulo: Cortez.

GRABOWSKI, Gabriel. 2005. Política pública de financiamento da educação profissional: um estudo de caso do Programa Nacional de Expansão da Educação Profissional. Exame de Qualificação (Doutorando), Porto Alegre: Programa de Pós-Graduação em Educação, Universidade Federal do Rio Grande do Sul.

GRAMSCI, Antonio. 1981. Concepção dialética da história. $4^{\mathrm{a}}$ ed. Rio de Janeiro: Civilização Brasileira.

. 1989. Caderno 12: apontamentos e notas esparsas para um conjunto de ensaios sobre a história dos intelectuais. Tradução, apresentação e comentário de Paolo Nosella. São Carlos: Ufscar. Documento inédito datilografado e fotocopiado.

2001. Os intelectuais: o princípio educativo, jornalismo. $2^{\mathrm{a}}$ ed. Rio de Janeiro: Civilização Brasileira. (Cadernos do Cárcere, v. 2).

GTPE-SINDOCEFET-PR (org.). 2005. Politicas públicas para a educação profissional e tecnológica: uma análise crítica, v. 1. $1^{\mathrm{a}}$ ed. Curitiba: Sindocefet-PR, p. 1-47.

INEP (Instituto Nacional de Estudos e Pesquisas Educacionais). 1999. Matrizes curriculares de referência. $2^{\mathrm{a}}$ ed. Brasília.

KUENZER, Acácia Zeneida. 1991. Ensino Médio: uma nova concepção unificadora de ciência, técnica e ensino. In: GARCIA, Walter; CUNHA, Célio (coords.). Politecnia no ensino médio. São Paulo: Cortez; Brasília: Seneb, p. 113-123. (Cadernos Seneb, 5).

2005. As propostas do decreto para a regulamentação do ensino médio e da educação profissional: uma análise crítica. Disponível em: <GtTrabEducandep@yhaoo.grupos.com.br $>$. Acesso em: 13 jan. 2005. Documento inédito “As diferentes versões", p. 1-5. 
LIBÂNEO, José Carlos. 1986. Democratização da escola pública: a pedagogia críticosocial dos conteúdos. $4^{\mathrm{a}}$ ed. São Paulo: Loyola.

LIMA FILHO, Domingos Leite. 2002. Impactos das recentes políticas públicas de educação e formação de trabalhadores: desescolarização e empresariamento da educação profissional. Perspectiva, v. 20, n. 2, p. 269-302.

2003. A desescolarização da escola: impactos da reforma da educação profissional (período 1995-2002). Curitiba: Torre de Papel.

MACHADO, Lucília Regina de Souza. 1989a. Trabalho, tecnologia e ensino politécnico. Revista de Educação, n. 4, p. 26-30. 1989b. Politecnia, escola unitária e trabalho. São Paulo: Cortez/Autores Associados.

MANACORDA, Mario Alighiero. 1990. O princípio educativo em Gramsci. Porto Alegre: Artes Médicas.

MARONI, Amnéris. 1982. A estratégia da recusa: análise das greves de maio/78. São Paulo: Brasiliense.

MARX, Karl. 1977. Crítica del Programa de Gotha. Moscou: Progreso.

1982. O capital, v. 1, t. 1. $8^{a}$ ed. São Paulo: Difel.

MARX, Karl; ENGELS, Friedrich. 1984. A ideologia alemã: $1^{\circ}$ capítulo seguido das teses sobre Feuerbach. São Paulo: Moraes.

MEC (Ministério da Educação). 1997. Padrões curriculares nacionais. Brasília.

MEC (Ministério da Educação). Secretaria de Educação Média e Tecnológica. Programa de Expansão da Educação Profissional. 2001. Educação profissional: legislação básica. $5^{\text {a }}$ ed. Brasília.

2004. Políticas públicas para a educação profissional e tecnológica. Brasília. 2005a. Projeto Escola de Fábrica. Disponível em: <portal.mec.gov.br/ setec/index.php $>$. Acesso em: 23 jan. 2005.

MELLO, Guiomar Namo de. 1988. Magistério de $1^{\circ}$ grau: da competência técnica ao compromisso político. $9^{a}$ ed. São Paulo: Cortez/Autores Associados.

MOISÉS, José Álvaro. 1982. Lições de li- berdade e de opressão: o novo sindicalismo e a política. Rio de Janeiro: Paz e Terra.

MORAES, Ignes Navarro de. 1991. Educação brasileira: uma nova Lei de Diretrizes e Bases. Universidade e Sociedade, n. 1, p. 37- 46.

MOURA, Dante Henrique. 2004. A formação de docentes, gestores e pessoal técnico-administrativo das IEPT: uma perspectiva socialmente produtiva. In: II Seminário Regional para a Discussão da Proposta de Anteprojeto de Lei Orgânica para a EPT, São Paulo. 14 quadros.

NOSELLA, Paolo. 1983. Compromisso político como horizonte da competência técnica. Educação \& Sociedade, n. 14, p. 91-98.

1989. O trabalho como princípio educativo em Gramsci. Educação \& Realidade, v. 14, n. 2, p. 3-20.

2005. Compromisso político e competência técnica: 20 anos depois. Educação \& Sociedade, v. 26, n. 90, p. 223-238.

OLIVEIRA, Betty Antunes de; DUARTE, Newton. 1987. Socialização do saber escolar. São Paulo: Cortez. (Coleção Polêmicas do Nosso Tempo, n. 18).

PAIVA, Vanilda. 1984. Anotações para um estudo sobre populismo católico e educação no Brasil. In: (org.). Perspectivas e dilemas da educação popular. Rio de Janeiro: Graal, p. 227-265.

PAOLI, Maria Célia; SADER, Eder; TELLES, Vera da Silva. 1983. Pensando a classe operária: os trabalhadores sujeitos ao imaginário acadêmico. Revista Brasileira de História, n. 6. p. 129-149.

PEREIRA, Luiz Augusto C. 2004. A formação de professores para a capacitação de trabalhadores da educação profissional e tecnológica. In: Encontro Regional Subsídios para a discussão da proposta de anteprojeto de lei orgânica de Educação Profissional e Tecnológica, Curitiba. (Mimeo). p. 1-17.

RAMOS, Marise. 2001. A pedagogia das competências: autonomia ou adaptação? São Paulo: Cortez.

. 2002. A educação profissional pela 
pedagogia das competências: para além da superfície dos documentos oficiais. Educação \& Sociedade, v. 23, n. 80, p. 405-427.

2005a. O público e o privado na educação profissional: as políticas do MEC. In: ADRIÃO, Thereza; PERONI, Vera. (orgs.). O público e o privado na educação: interfaces entre Estado e sociedade. São Paulo: Xamã, p. 31-57.

. 2005b. Algumas considerações pontuais visando contribuir para a participação do GT 'Trabalho e educação' na discussão sobre formação de professores para a educação profissional tecnológica. Disponível em: <GtTrabEducandep@yhaoo.grupos.com.br>. Acesso em: 4 jan. 2005. Arquivo "Crítica parecer EM + EP", p. 1-3.

RIBEIRO, Marlene. 1991. Ensino ou formação: a polêmica sobre o trabalho como princípio educativo gestado no processo de organização dos trabalhadores. Projeto de pesquisa para doutorado, Porto Alegre: Faculdade de Educação, Universidade Federal do Rio Grande do Sul.

. 1999. A originalidade de Paulo Freire no pensamento educacional brasileiro. Educação em Revista, n. 29, p. 15-30. . 2002. Ensino médio e educação profissional sob relações de hegemonia: terreno perdido ou construção de novas relações? Revista do Centro de Educação, v. 27, n. 1, p. 9-22.

. 2004. Dimensão pedagógica da violência na formação do trabalhador amazonense. Somanlu. Revista de Estudos Amazônicos, v. 1, n. 1. p. 55-80.

. 2005. Trabalho-educação numa perspectiva de classe: apontamentos para a educação dos trabalhadores brasileiros. Texto produzido para a conferência de abertura do III Simpósio Trabalho e Educação - NETE 10 Anos, Belo Horizonte: UFMG.

RIBEIRO, Marlene; LIMA FILHO, Domingos Leite. 2005. Relatório do GT 'Trabalho e educação' da $28^{a}$ Reunião Anual da Anped. (Fotocopiado).
RODRIGUES, José. 2005. Quarenta anos adiante: breves comentários a respeito do novo decreto de educação profissional. Trabalhonecessário. Revista Eletrônica do Neddate, v. 3, n. 1, p. 1-10.

RUMMERT, Sonia Maria. 2005. Projeto Escola de Fábrica: atendendo a 'pobres e desvalidos da sorte' do século XXI. Perspectiva. Dossiê Agenda Global e Educação Pública, v. 23, n. 2, p. 303-322.

SANTOS, Oder José dos. 1985. A questão da produção e da distribuição do conhecimento. Educação em Revista, n. 2, Belo Horizonte, p. 5-77.

SAVIANI, Dermeval. 1980. Educação: do senso comum à consciência filosófica. São Paulo: Cortez/Autores Associados.

1983. Competência política e compromisso técnico ou (o pomo da discórdia e o fruto proibido). Educação \& Sociedade, n. 15, p. 11-143.

1989. Repensando a relação trabalho-escola. Revista de Educação, n. 4, p. 13-16.

1991. Pedagogia histórico-crítica: primeiras aproximações. São Paulo: Cortez/Autores Associados.

2003. O choque teórico da politecnia. Trabalho, Educação e Saúde, n. 1, p. 131-152.

SILVA JR., João dos Reis. 2002. Mudanças estruturais no capitalismo e a política educacional do Governo FHC: o caso do ensino médio. Educação \& Sociedade, v. 23. n. 80 , p. 203-234.

SINGER, Paul. 2003. Para entender o mundo financeiro. São Paulo: Contexto.

THOMPSON, Edward P. 1984. Tradición, revuelta y conciencia de clase: estudios sobre la crisis de la sociedad industrial. Barcelona: Crítica.

TUMOLO, Paulo Sérgio. 2003. Trabalho, vida social e capital na virada do milênio: apontamentos de interpretação. Educação \& Sociedade, v. 24, n. 82, p. 159-180.

Recebido em 22/03/2006

Aprovado em 02/06/2006 
